the Quarterly Journal of Microscopical Science, and is, no doubt, by this time in the hands of zoologists.

But it is mere justice to my friend, Prof. Dendy, to place before our European colleagues the following facts in regard to Dr. Schauinsland's reference to the inactivity and lack of enthusiasm exhibited by Colonial zoologists in the matter of this most interesting member of our local fauna.

The Tuatara is quite properly "protected" by the Government of New Zealand; permission to obtain material for the in vestigation of its life-history was granted to Dr. Dendy, and the lighthouse-keeper on Stephen's Island, a Government servant, was permitted to collect the eggs and embryos for him. But subsequently, and without any communication with Dr. Dendy, and before he had obtained more than a few (if any) eggs, the Government also gave permission to Dr. Schauinsland to collect eggs, and moreover instructed their servant on Stephen's Island to give him every assistance.

In this instance, then, Dr. Schauinsland's charge of lack of enthusiasm is not only baseless, but wanton.

The following fact is not without bearing in this connection. A certain foreign zoologist was recently on a visit to New Zealand for the purpose of collecting the rarer and more characteristic animals, amongst others the Bulimoid pulmonate, Placostylus bovinus. Having obtained all the individuals living, as well as shells only, on which he could lay his hands, he proceeded to crush all the young ones he could see, and was heard to remark that if any future zoologist or conchologist wished for a specimen he would have to go to a certain town in Europe (and not to New Zealand).

Dunedin, N.Z., April I3. Wm. Blaxland Benham.

\section{THE GIPSY MOTH, AND ITS INTRODUCTION} INTO AMERICA.

M ANY persons, whether entomologists or not, must have noticed a rather slender, dark-coloured moth with feathery antennæ flying among bushes on the continent ; and a much larger, stout-bodied, whitish-grey moth, sitting on hedges, or on the trunks of trees. Dissimilar as these insects may appear, they are nevertheless the male and female of the Gipsy Moth (Porthetria dispar), the male of which flies about in the day-time like that of the Vapourer Moth (Notolophus antiquus), a small tawny-brown moth with a white spot on the fore-wings, which has an apterous female, and the caterpillar of which feeds on a great variety of trees and shrubs (Fig. I).

The two moths are not distantly related, both belonging to the family Liparidae, but while the Vapourer Moth is so common with us that it is often seen flying even in the streets of London, wherever there are any trees near, the Gipsy Moth is now so rare here as to be thought to be extinct in England, though it is abundant, and often destructive, on the continent. The entomologists of the last century speak of it as very rare in England, and as having been introduced into the orchards of Chiswick, where, however, it failed to establish itself. Subsequently, Stephens wrote that it was rare in the neighbourhood of London, though it had been taken occasionally at Coombe Wood, but that it was abundant in the fens of Huntingdonshire. It is very singular that several insects of general distribution on the continent, among which we may specially mention Papilio machaon, Lycaena dispar, and Porthetria dispar, should have ound their last stronghold in England, like the Britons and the Saxons, in the fens, though the Gipsy Moth was formerly common in fens which are still undrained, as well as in some which no longer exist. It is also remarkable that the English fen-specimens of both the butterfly and moth named dispar were much larger and finer on an average than the continental representatives of the same species; and that both should have become practically extinct in England since the drainage of the fens.

In I 857 , Stainton wrote of the Gipsy Moth: "This species is apparently less common here than formerly," and mentioned Halton in Buckinghamshire, and Stowmarket in Suffolk, as localities. After this time, the moth became rapidly scarcer, and I am not aware that any authentic British specimens have been taken of late years, though a degenerate breed of British origin was preserved among entomologists for a long time, and may be still.

Far different has been the history of the Gipsy Moth in America, where it is not indigenous, though the insect extends across the northern part of Asia-Europe from England to Japan, and is abundant, if not destructive, in most parts of its range.

Thirty years ago, a French entomologist, named Leopold Trouvelot, was living at Medford, in Massachusetts. $\mathrm{He}$ was engaged in carrying on a series of experiments on rearing moths, which he thought might possibly be made useful as silk producers. Among other species, he imported the Gipsy Moth, and, by some accident, some of the insects escaped from his custody into his own or the neighbours' gardens. The most

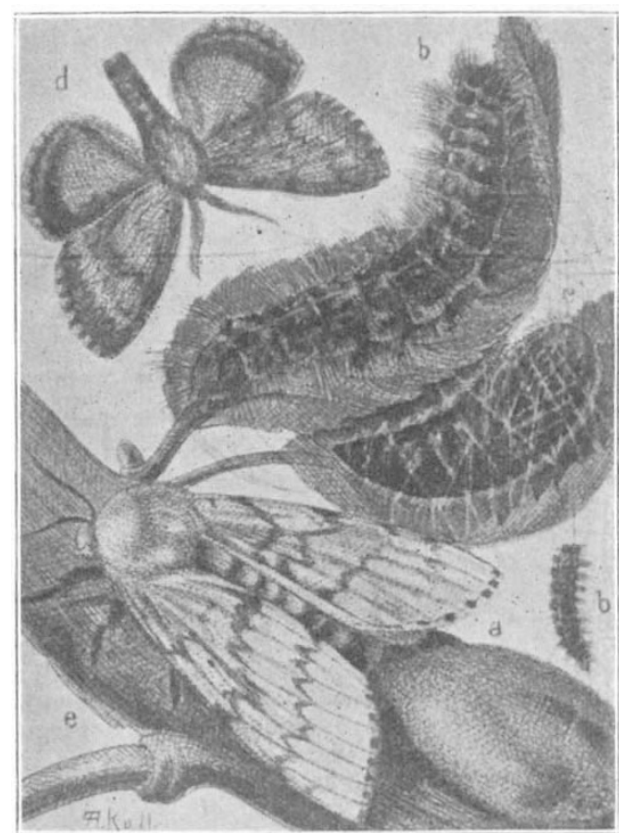

FIG. 1.-Gipsy Moth : $a$, egg mass ; $b$, caterpillars ; $c$, chrysalis ; $d$, male moth ; $e$, female moth. (Reproduced from "Insects: Friends and Foes." By Dr. W. Egmont Kirby. Partridge and Co.)

probable story is that some eggs were blown out of the window, and that $M$. Trouvelot was much concerned at not being able to find them; for the female is a very sluggish insect, which is seldom or never seen on the wing.

Had prompt measures been taken, the insect might possibly have been exterminated; but it does not seem to have attracted any attention till about $\mathrm{I} 880$, when the people then living in or near M. Trouvelot's former residence began to be troubled with swarms of caterpillars, though what they were, and whence they came, was then unknown. For several years the neighbouring houses suffered severely, apple- and pear-trees and shade-trees being stripped of their leaves and killed, and the caterpiliars creeping all over and into the houses. Nevertheless, they spread very slowly along the street, and into the surrounding woods till 1889 , when the insects multiplied so much that the caterpillars stripped all the trees in the immediate neighbourhood of M. Trouvelot's old house, and then marched forth in NO. I 543 , VOL. 60] 
armies sufficient to blacken the streets, in search of fresh provender. A terrible account of the ravages of the caterpillars is given by those who witnessed them, and the town became thoroughly alarmed. Specimens of the insect were sent to the Agricultural Experiment Station at Amherst, Massachusetts, where it was identified by Mrs. C. H. Fernald and her son, in the absence of Prof. Fernald, who happened to be travelling in Europe

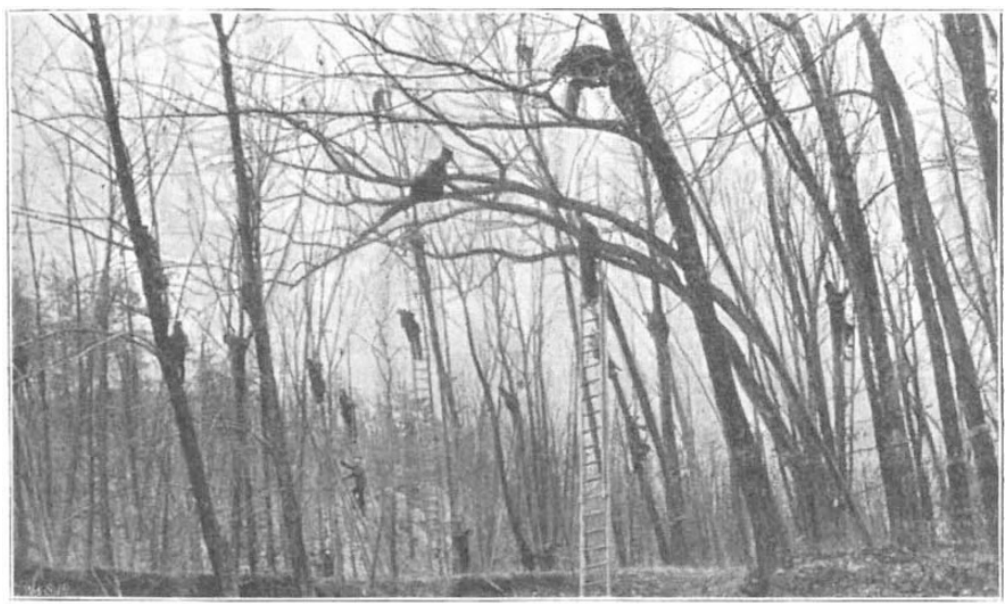

FIG. 2.-Destroying the eggs of the Gipsy Moth in the Middlesex Fells Reservation.

appointed entomological adviser to the Committee. During the first six weeks of the year, three-quarters of a million egg-clusters were destroyed, estimated to contain from three to five hundred millions of eggs. ${ }^{1}$ During the fine season, the trees were sprayed, and in autumn egggathering again commenced. Seventy-five thousand dollars were spent this year, and, though the insect was not exterminated, its numbers were seriously reduced. By this time, no less than thirty townships were found to be infested with the insect.

Year by year the campaign against the moth has been continued on similar lines, though impeded by frequent delays in the appropriation grants, as well as by the insufficiency of the amounts, and in $1896 \mathrm{Mr}$. E. H. Forbush (the field director in the work of destroying the Gipsy Moth) and Prof. Fernald published a volume of 600 pages on the insect and its history, from which much of the information in the present paper is derived. We have also just received the "Report of the State Board of Agriculture on the Work of Extermination of the Gypsy Moth," presented to the Senate and House of Representatives of the Commonwealth of Massachusetts on January I, I 898, and containing an account of the work of the Committee during 1897 . From this we learn that the Com-

at the time. On his return, he at once visited Medford, and recommended spraying all infested trees with Paris Green, an arsenical preparation which had previously been employed with great success in checking the ravages of the Colorado Potato Beetle. A pamphlet containing descriptions and figures of the insect in all its stages, with hints for its destruction, was printed and largely circulated ; and the veteran agricultural entomologist, Prof. C. V. Riley, gave it as his opinion that if Prof. Fernald's recommendations were carried out at all strictly, there was little fear of the insect spreading, and that it might be entirely exterminated with the expenditure of a little time and money.

In March I890 a Commission was appointed with full authority to take any necessary measures for the destruction of the pest, and a sum of 25,000 dollars was placed at the disposal of the Commissioners, any person convicted of knowingly spreading the insect, or interfering with the work of the Commissioners, being rendered liable to heavy fines or imprisonment.

As soon as the Commissioners had made a preliminary investigation, it was discovered that the infested area was far larger than had been supposed, and that the grant of 25,000 dollars was wholly insufficient. Large quantities of eggs were destroyed,

brushwood cleared, and trees sprayed with Paris Green, while the principal roads leading from the infested district were guarded by policemen, whose duty was to see that caterpillars should not be carried about by passing vehicles.

In I89I, a fresh Commission was appointed, under the auspices of several of the most eminent American entomologists, and Prof. C. H. Fernald was subsequently NO. I 543, VOL. 6o] mittee applied for a grant of 200,000 dollars for the work of that year, and the Legislature promptly granted them three-quarters of the amount. Much work was done (Figs. 2 and 3), and infested districts were cleared as far as the amount would permit, but the Committee's recommendation was for "an appropriation of not less than 200,000 dollars a year for a term of not less than five years, and then an appropriation of not

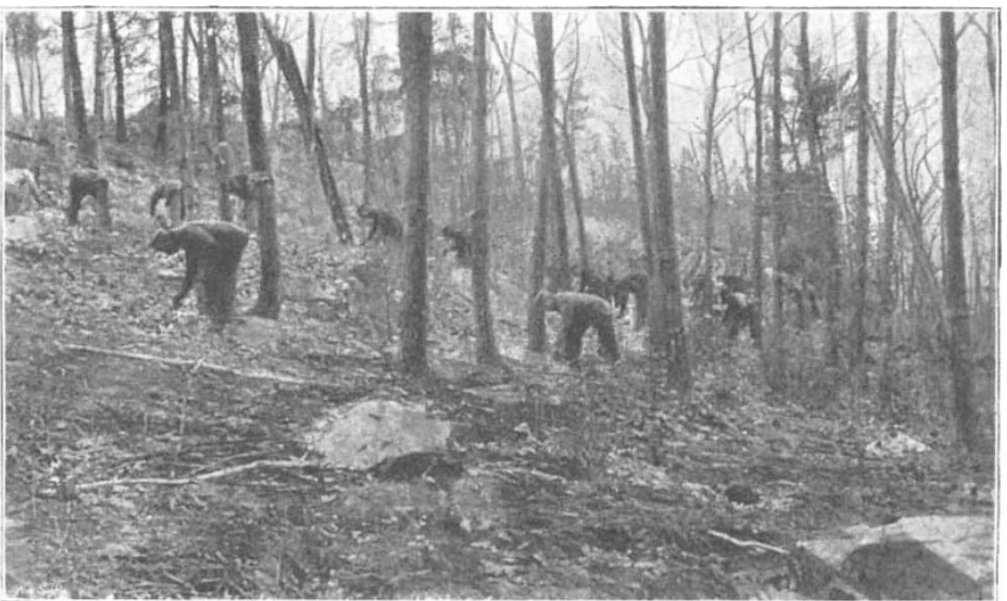

FiG. 3.-Destroying masses of Gipsy Moth eggs on rocks and ledges.

less than 100,000 dollars a year for a term of not less than five years. After this, an appropriation of perhaps 15,000 dollars a year for a period of five years will be required." On this, Prof. Fernald remarks : "The first five years, with the full appropriation of 200,000 dollars a year, will reduce the territory to such an extent that

1 These eggs are laid in clusters and covered with down from the abdomen of the female. 
with 100,000 dollars a year for the next five years the insect will be practically exterminated, and the remaining five years will be spent in a careful watch of the entire territory, lest a few insects might have been overlooked in isolated localities. Unless a sufficient amount is appropriated to make a very substantial gain each year, it would be better to abandon the work entirely."

It is perhaps not surprising that, after having already spent half a million of dollars in what many persons, rightly or wrongly, considered the hopeless task of exterminating a single insect, the Committee's application for a continuous grant of 200,000 dollars annually should have met with much opposition. A proposal was made to reduce the amount of the grant for 1898 to 75,000 dollars; but it was successfully resisted, and ultimately the full amount of 200,000 dollars asked for was granted for the year.

Another European moth-pest has lately been introduced into America - the Wood Leopard Moth (Zeuzera pyrina), which is at present rapidly destroying the shadetrees of New York. But this insect is still more difficult to deal with than the Gipsy Moth, for its naked yellow, black-spotted caterpillar feeds inside the wood of the trees, like that of the Goat Moth, to which it is allied; whereas the black, red-spotted tufted caterpillar of the Gipsy Moth feeds exposed on the leaves of its foodplants.

Different countries exchange their injurious animals and plants from time to time, but no one can tell beforehand which species are likely to establish themselves and to become injurious. We have seen that the Gipsy Moth had ample opportunities of becoming as injurious in England as in America ; but, nevertheless, it has died out.

On the other hand, the Woolly Aphis (Schizoneura lanigera), which is one of the worst pests of our appletrees, is said to have come from America, and is often called the American Blight. The vagaries of plants are equally uncertain. Our common water-cress, a harmless plant enough, one would think, has developed a giant form in New Zealand, which is blocking up the watercourses. In the middle of the present century, an American water-plant (Anacharis alsinastrum) was introduced into England by some accident, like the Gipsy Moth into America, when it was called the new water-weed, and caused great trouble for a time by choking up rivers and ponds. Fortunately, however, after a few years the plant seems to lose its vitality, and ceases to become a pest, owing, as is supposed, to the female plant only having been introduced into England, and it therefore propagates by buds alone.

Time will show whether the Gipsy Moth will continue its devastations in America, or whether it will either be exterminated by the energetic measures taken for its destruction, or by the conditions of American life proving ultimately unfavourable to it, notwithstanding its first rapid increase. It is evident that, although we cannot avoid the accidental introduction of injurious plants and animals from abroad, some care should be taken in introducing any which might become injurious into another country. M. Trouvelot's experiments were intended to benefit the silk industry in the United States; but they have resulted in letting loose a pest which hundreds of workers are now striving, at enormous annual expense, to eradicate if they can. Let us hope that their efforts may be crowned with success, for otherwise the whole of temperate North America may suffer more or less severely, as the infested districts of Massachusetts are now suffering.

W. F. KIRBY.

\section{THE AUSTRALASIAN ASSOCIATION. ${ }^{1}$}

$A \mathrm{~N}$ Association for the Advancement of Science which A can produce, as the record of one year's proceedings, such a volume as the one before us, is at once an indication that a widely-spread interest in science and a vigorous scientific activity already exist, and a promise of future progress. It is a volume on the production of which the Australasian Colonies may be sincerely congratulated.

The Australasian Association for the Advancement of Science held its first session at Sydney in 1888 ; it next met in Melbourne in 1890 ; then in Christchurch (New Zealand) in $189 \mathrm{I}$, in Hobart (Tasmania) in 1892 , in Adelaide in 1893, in Brisbane in 1895 , and in Sydney again in 1898 . We do not know whether the fact that only one meeting was held in the five years from 1893 to I 898 was connected with the commercial difficulties through which Australia has recently passed; if so, we trust that the resumption of meetings last year may be taken as a sign of returning prosperity.

The constitution of the Association and the order of proceedings at the general meetings are evidently closely modelled on those of the British Association. The public proceedings begin with an evening address delivered by the President for the year ; on the following days, meetings of the several Sections are held, relieved by evening lectures, including one to "working men," conversazioni and concerts, garden parties (with "the number of invitations limited"), Saturday afternoon excursions, and, to wind up the whole entertainment, excursions going further afield. One who is accustomed to the doings at the annual gatherings of the British Association would find himself familiar with the whole programme of its Colonial counterpart. Perhaps he might find his way into a Section whose name and subject he had not been used to in the old country, but he would find most of them just what he was accustomed to, as the following list of Sections will show, namely:-Section A-Astronomy, Mathematics, and Physics; Section B-Chemistry; Section C-Geology and Mineralogy; Section DBiology, with the sub-departments Botany and Zoology; Section E-Geography; Section F-Ethnology and Anthropology ; Section G-Economic Science and Agriculture; Section $\mathrm{H}$-Engineering and Architecture; Section I-Sanitary Science and Hygiene; Section JMental Science and Education.

To review with any completeness a volume of over eleven hundred pages, dealing with the almost unlimited range of subjects covered by the ten Sections here enumerated, is obviously impossible. All that we can attempt is to indicate some of what appear to us to be among its more noteworthy contents.

There can be little doubt that the most serious contribution to pure science contained in it is the "Report on our Knowledge of the Thermodynamics of the Voltaic Cell," by Mr. E. F. J. Love. This is a really admirable account of the results that have been obtained, chiefly by Lord Kelvin, Willard Gibbs, and von Helmholtz, by the application of thermodynamic considerations to voltaic phenomena. These results are deduced simply and concisely, and are discussed throughout in relation to the experimental tests to which they have been subjected by various observers. It would, we think, be welcome to many physicists if this paper were reprinted in some more generally accessible publication than the bulky volume before us.

In his presidential address to Section A, Mr. Baracchi, Government Astronomer at Melbourne, gives a very interesting account of the great International Photographic Survey of the Heavens, and especially of the share in this

1 "Report of the Seventh Meeting of the Australasian Association for the Advancement of Science," held at Sydney, r898. Pp. lii + rr61. 